\title{
Biodiesel Production Process Optimization from Sugar Apple Seed Oil (Annona squamosa) and Its Characterization
}

\author{
Siddalingappa R. Hotti ${ }^{1}$ and Omprakash D. Hebbal ${ }^{2}$ \\ ${ }^{1}$ Department of Automobile Engineering, PDA College of Engineering, Gulbarga Karnataka 585102, India \\ ${ }^{2}$ Department of Mechanical Engineering, PDA College of Engineering, Gulbarga Karnataka 585102, India
}

Correspondence should be addressed to Siddalingappa R. Hotti; hottisr@gmail.com

Received 21 July 2014; Accepted 22 December 2014

Academic Editor: Abdurrahman Saydut

Copyright (C) 2015 S. R. Hotti and O. D. Hebbal. This is an open access article distributed under the Creative Commons Attribution License, which permits unrestricted use, distribution, and reproduction in any medium, provided the original work is properly cited.

\begin{abstract}
This paper presents the production of biodiesel from nonedible, renewable sugar apple seed oil and its characterization. The studies were carried out on transesterification of oil with methanol and sodium hydroxide as catalyst for the production of biodiesel. The process parameters such as catalyst concentration, reaction time, and reaction temperature were optimized for the production of sugar apple biodiesel (SABD). The biodiesel yield of $95.15 \%$ was noticed at optimal process parameters. The fuel properties of biodiesel produced were found to be close to that of diesel fuel and also they meet the specifications of ASTM standards.
\end{abstract}

\section{Introduction}

Energy is the critical input factor for the socioeconomic development and welfare of human being of any country. Fossil fuels are the major sources for the energy demand since their exploration. India is highly dependent on crude oil; net import of crude oil during 2011-12 is 171.73 million metric tons [1]. Due to limited reserves of fossil fuels, environmental degradation, and volatility in fuel prices, there is a growing need for energy security and protection of the environment. Country like India with an agricultural background has wasteland of about 55.27 million hectares [2], which can be utilized for growing plants/crops, which produce nonedible oil in appreciable quantity. Thus indigenously produced biodiesel, which is defined as the mono-alkyl esters of vegetable oils or animal fats, obtained by transesterifying oil or fat with an alcohol [3], is considered one of the options to substitute the petroleum fuels.

Many researchers have produced the biodiesel from nonedible oil, which include Jatropha (Jatropha curcas) oil [48], Karanja or Honge (Pongamia pinnata/glabra) seed oil [7, 9-12], Polanga (Calophyllum inophyllum) seed oil [13], rubber
(Hevea brasiliensis) seed oil $[14,15]$, mahua (Madhuca indica) oil [16], tobacco (Nicotiana tabacum) seed oil [17], bitter almond (Prunus dulcis) oil [18], castor (Ricinus communis) seed oil $[19,20]$, okra (Hibiscus esculentus) seed oil [21], Kusum (Schleichera trijuga) oil [22], Simarouba (Simarouba glauca) [23], milo (Thespesia populnea) seed oil [24, 25], milk thistle (Silybum marianum) seed oil [26], and wild safflower (Carthamus oxyacantha Bieb) seed oil [27]. In the production process of biodiesel, the effects of process parameters such as alcohol to oil molar ratio, catalyst concentration, reaction time, and reaction temperature have been studied and optimized. the fuel properties of produced biodiesel have been investigated and compared with the standard specifications for assessing their feasibility to substitute the petroleum fuels. However there are many other nonedible oils for which process parameters are not being optimized. One among them is sugar apple (Annona squamosa) seed oil.

Annona squamosa, the sugar apple, sweetsop, or sugarpineapple, is a species in the Annonaceae family. Sugar apple is grown in lowland tropical climates worldwide, including southern Mexico, the Antilles, and Central and South America, Tropical Africa, Australia, Indonesia, Polynesia, 
TABLE 1: Fatty acid composition of sugar apple seed oil.

\begin{tabular}{lc}
\hline Fatty acid composition & Weight \% \\
\hline Lauric acid (C12:0) & 0.08 \\
Palmitic acid (C16:0) & 17.79 \\
Stearic acid (C18:0) & 4.29 \\
Oleic acid (C18:1) & 39.72 \\
Linoleic acid (C18:2) & 29.13 \\
Linolenic acid (C18:3) & 1.37 \\
Arachidonic acid (C20:4) & 1.06 \\
Behenic acid (C22:0) & 2.01 \\
\hline
\end{tabular}

Source: [29].

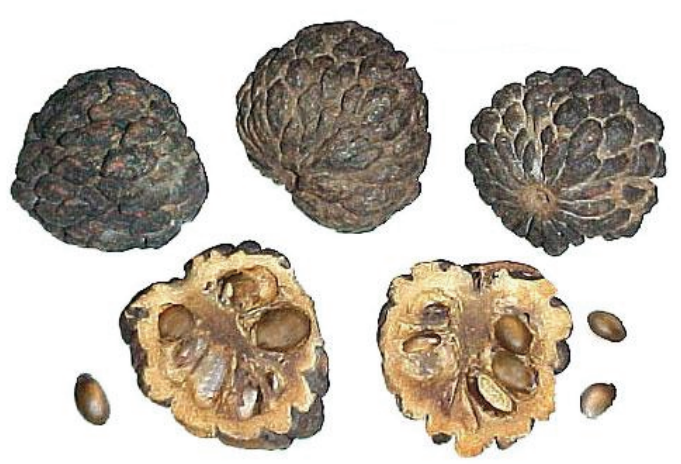

FIgURE 1: Sugar apple (Annona squamosa) fruits and seeds.

and USA, Hawaii and Florida. It was introduced to India and the Philippines by the Spanish and Portuguese in the 16th century and has been cultivated there ever since [28].

The sugar apple tree ranges from 3 to $6 \mathrm{~m}$ in height with open crown of irregular branches and somewhat zigzag twigs. Deciduous leaves, alternately arranged on short, hairy petioles, are lanceolate or oblong, blunt tipped, 5 to $15 \mathrm{~cm}$ long, and 2 to $5 \mathrm{~cm}$ wide with dull-green on the upper side, and pale, with a bloom on the lower side. The leaves are slightly hairy when young and aromatic when crushed. Along the branch tips, opposite the leaves, the fragrant flowers are borne singly or in groups of 2 to 4 . They are oblong, 2.5 to $3.8 \mathrm{~cm}$ long, never fully open with $2.5 \mathrm{~cm}$ long, drooping stalks and 3 fleshy outer petals, yellow-green on the outside, and pale-yellow from the inside with a purple or dark-red spot at the base. The 3 inner petals are merely tiny scales. The compound fruit is nearly round, ovoid, or conical and it is 6 to $10 \mathrm{~cm}$ long. The fruit is thick rind composed of knobby segments, pale-green, gray-green, bluish-green, or, in one form, dull, deep-pink externally (nearly always with a bloom), separating when the fruit is ripe and revealing the mass of conically segmented, creamy-white, glistening, delightfully fragrant, juicy, sweet, and delicious flesh. Many of the segments enclose a single oblong-cylindrical, black or dark-brown seed about $1.25 \mathrm{~cm}$ long. There may be a total of 20 to 38 , or perhaps more, seeds in the average fruit [30]. The sugar apple, fruits, and seeds are shown in Figure 1.

The emphasis of present work is to produce biodiesel from Annona squamosa seed oil by transesterification process

$$
\begin{array}{llcc}
\mathrm{CH}_{2}-\mathrm{OCOCR}_{1} & \text { Glycerol } & \begin{array}{c}
\text { Methyl esters } \\
\text { (biodiesel) }
\end{array} \\
\mathrm{CH}_{2}-\mathrm{OCOR}_{3} & \begin{array}{l}
\text { Methanol } \\
\text { (alcohol) }
\end{array} & \mathrm{CH}_{2} & \stackrel{\mathrm{CH}_{2}-\mathrm{OH}}{\mathrm{C}}-\mathrm{COOCH}_{3} \\
\text { Triglyceride } & \text { Catalyst }-\mathrm{OH}+\mathrm{R}_{2}-\mathrm{COOCH}_{3} & \mathrm{R}_{3}-\mathrm{COOCH}_{3} \\
\hline
\end{array}
$$

FIgURE 2: Transesterification reaction mechanism $\left(\mathrm{R}_{1}, \mathrm{R}_{2}\right.$, and $\mathrm{R}_{3}$ are long chain hydrocarbons, sometimes called fatty acid chains).

using methanol and sodium hydroxide $(\mathrm{NaOH})$ as catalyst and to study the effect of process parameters such as alcohol to oil molar ratio, reaction time, and reaction temperature on the yield of biodiesel. Further the physicochemical properties of produced biodiesel are investigated and compared with diesel and standard specifications of biodiesel to assess its feasibility to replace the petroleum fuel.

\section{Materials and Method}

2.1. Oil Extraction. The seeds were collected from the different households as one discards the seeds after consuming the fruit. The collected seeds were dried and crushed in a mechanical expeller. For complete extraction of oil the seeds were passed four times through the expeller. The neat oil is allowed to settle for 48 hours and after that oil is stored in an airtight container to avoid oxidation.

2.2. Fatty Acid Composition of Sugar Apple Seed Oil. The vegetable oil extracted from a plant is composed of triglyceride, which is an ester derived from three fatty acids and one glycerol. The fatty acid composition of sugar apple seed oil (SASO) is given in Table 1.

2.3. Transesterification Reaction. The transesterification reaction was carried out in a laboratory scale batch reactor equipped with thermometer and condenser; the heating and stirring were done with a hot plate magnetic stirrer system. In each set of experiment $50 \mathrm{~g}$ of oil was heated to the predefined temperature and after attainment of predefined temperature the mixture of catalyst and methanol was transferred to reactor and all the predefined sets of transesterification reaction conditions were measured from this point for each set of experiment. The transesterification reaction mechanism is as shown in Figure 2. Stoichiometrically $3: 1$ molar ratio of alcohol to oil is needed for completion of transesterification reaction, but many researchers reported that biodiesel yield is maximum with excess molar ratio of alcohol to oil. Hence in the present investigation, in each set of experiment, $6: 1$ molar ratio of alcohol to oil and constant stirrer speed were maintained.

After the completion of predefined set of transesterification reaction conditions the reaction mixture was transferred into a separating funnel left for 60 minutes to separate into biodiesel and glycerol. The lower layer of glycerol was removed and the upper layer of crude biodiesel is washed several times with hot water at $50^{\circ} \mathrm{C}$ to remove the impurities, 
TABLE 2: ASTM standard test methods used for determination of fuel properties.

\begin{tabular}{lcc}
\hline Property & Test method & Unit \\
\hline Flash point & D93-10 & ${ }^{\circ} \mathrm{C}$ \\
Density & $\mathrm{D} 1298-99$ & $\mathrm{~kg} / \mathrm{m}^{3}$ \\
Kinematic viscosity & $\mathrm{D} 445-09$ & $\mathrm{~mm}^{2} / \mathrm{s}$ \\
Calorific value & D240-09 & $\mathrm{MJ} / \mathrm{kg}$ \\
Calculated cetane index & D976-06 & - \\
cetane number) & D5555-95 & $\mathrm{mg} \mathrm{KOH} / \mathrm{g}$ \\
Acid number & $\mathrm{D} 130-04$ & - \\
Copper strip test & $\mathrm{D} 874-07$ & $\mathrm{w} / \mathrm{w}(\%)$ \\
Sulfated ash & $\mathrm{D} 189-06$ & $\mathrm{w} / \mathrm{w}(\%)$ \\
Conradson carbon residue & $\mathrm{D} 86-09$ & ${ }^{\circ} \mathrm{C}$ \\
Distillation & & \\
\hline
\end{tabular}

such as residual catalyst, methanol, soap, and glycerol. The removal of impurities was confirmed by measuring the $\mathrm{pH}$ of water. The biodiesel was dried by heating it to a temperature of $110^{\circ} \mathrm{C}$ and allowed overnight for evaporation and cooling. The final product was weighed to determine the biodiesel yield.

2.4. Analytical and Test Methods. The mean molecular weight, saponification number (SN), iodine value (IV), and cetane number $(\mathrm{CN})$ were determined from the fatty acid composition of oil using (1), (2), (3), and (4); respectively $[18,31]$ :

$$
\mathrm{MW}_{\mathrm{oil}}=3 \times \sum\left(\mathrm{MW}_{i} \times x_{i}\right)+38,
$$

where $\mathrm{MW}_{\text {oil }}$ stands for molecular weight of SASO and $\mathrm{MW}_{i}$ and $x_{i}$ stand for molecular weight and mass fraction of $i$ th fatty acid; respectively,

$$
\begin{gathered}
\mathrm{SN}=\sum\left(560 \times \frac{A_{i}}{\mathrm{MW}_{i}}\right), \\
\mathrm{IV}=\sum\left(254 \times D \times \frac{A_{i}}{\mathrm{MW}_{i}}\right), \\
\mathrm{CN}=46.3+\frac{5458}{\mathrm{SN}}-0.225 \times \mathrm{IV},
\end{gathered}
$$

where $A_{i}$ is the percentage, $D$ is the number of double bonds, and $\mathrm{MW}_{i}$ is the molecular mass of each component.

The fuel properties of sugar apple seed oil (SASO) and sugar apple biodiesel (SABD) were determined as per the ASTM standards as given in Table 2.

In this paper the biodiesel yield was calculated using

$$
\text { Biodiesel yield }=\frac{m_{\text {biodiesel }}}{m_{\text {oil }}} \times 100 \text {, }
$$

where $m_{\text {biodiesel }}$ is the weight of SABD after purification and $m_{\mathrm{oil}}$ is the weight of SASO.

\section{Results and Discussion}

3.1. Oil Content of Sugar Apple Seeds. The oil extracted from the mechanical expeller was weighed after filtering; it was found that the sugar apple seeds contain moderate quantity of oil, $24.5 \mathrm{w} / \mathrm{w} \%$ oil, and thus it can be suitable feedstock for the production of biodiesel.

3.2. Fatty Acid Composition Analysis. Generally three main types of fatty acids are present in triglyceride and they are saturated, monounsaturated, and polyunsaturated. The quality of biodiesel will be affected by the fatty acid composition of oil, preferably the vegetable oil should have low saturated and low polyunsaturated fatty acid composition, and the composition of monounsaturated fatty acid should be high. Table 1 shows the fatty acid composition of SASO and it contains predominant amount of monounsaturated fatty acid composition, that is, $39.72 \%$, followed by $31.56 \%$ of polyunsaturated fatty acid and $24.07 \%$ of saturated fatty acids. The major fatty acids present in the SASO were oleic acid, $39.72 \%$, linoleic acid, 29.13\%, palmitic acid, $17.79 \%$, and stearic acid, $4.29 \%$. Thus the SASO can be classified as oleic-linoleic oil.

3.3. Physicochemical Properties of $S A S O$ and $S A B D$. The physical and chemical properties of SASO and SABD were determined as per the ASTM standard test procedures and tabulated in Table 3. The iodine value of SASO is $118 \mathrm{mgI}_{2} / \mathrm{g}$, as the iodine value is higher, which indicates the unsaturation of SASO. The heating of these higher fatty acids results in polymerization of glycerides, which necessitates the limitation of unsaturated fatty acids; otherwise, it leads to formation of deposits and deterioration of lubricating oil. The saponification of SASO was 192, which indicates that the SASO is normal triglyceride and useful in production of soaps. The FFA (free fatty acid) content of oil is $0.965 \%$, as it is less than the biodiesel that can be produced using single stage transesterification process, that is, by base-catalyzed transesterification process. The flash points of SASO, SABD, and diesel were 235,161 , and 54 degrees Celsius, respectively. The flash points of SASO and SABD are found to be much higher in comparison with diesel, which helps in safe storage and transportation. The densities of SASO and SABD were higher than that of diesel, which may be due to the presence of higher molecular weight triglycerides. The kinematic viscosity of SASO was found to be $42.63 \mathrm{~mm}^{2} / \mathrm{s}$, which is much higher than that of diesel; hence the direct use of SASO may lead to poor combustion, untimely wear of fuel pumps, and injector. The viscosity of SASO was reduced by converting it to biodiesel and it was found to be $5.90 \mathrm{~mm}^{2} / \mathrm{s}$, which is within the limits of standard specification for biodiesel fuel. Calorific values of SASO, SABD, and diesel were found to be $37.95,40.48$, and $43.00 \mathrm{MJ} / \mathrm{kg}$, respectively. The calorific values of studied oil and biodiesel are found to be lower than that of diesel, which may be due to the difference in chemical composition or presence of oxygen molecule in molecular structure of oil. The other parameters, that is, cetane number, calculated cetane index, sulfated ash, carbon residue, copper strip corrosion, and distillation temperature, were found to be within the limits of standard specifications for biodiesel fuel. 
TABLE 3: Physiochemical properties of SASO and SBD in comparison with commercially available diesel and ASTM standard specifications for biodiesel fuel.

\begin{tabular}{|c|c|c|c|c|}
\hline Property & SASO & SABD & $\begin{array}{c}\text { Commercially available } \\
\text { diesel }\end{array}$ & $\begin{array}{c}\text { Standards specifications for } \\
\text { biodiesel fuel, ASTM D6751-09a }\end{array}$ \\
\hline Iodine value $\left(\mathrm{mg} \mathrm{I}_{2} / \mathrm{g}\right)$ & 118 & - & - & \\
\hline Saponification number & 192 & - & - & \\
\hline Acid number (mg KOH/g) & 1.93 & 0.34 & - & $0.50 \max$ \\
\hline Flash point $\left({ }^{\circ} \mathrm{C}\right)$ & 235 & 161 & 54 & $130 \mathrm{~min}$ \\
\hline Density $\left(\mathrm{kg} / \mathrm{m}^{3}\right)$ & 910 & 865 & 830 & $870-900$ \\
\hline $\begin{array}{l}\text { Kinematic viscosity } \\
\left(\mathrm{mm}^{2} / \mathrm{s}\right) \text { at } 40^{\circ} \mathrm{C}\end{array}$ & 42.63 & 5.90 & 2.4 & $1.9-6.0$ \\
\hline Calorific value (MJ/kg) & 37.95 & 40.48 & 43.00 & \\
\hline Cetane number & 47.93 & - & - & $47 \mathrm{~min}$ \\
\hline Calculated cetane index & - & 53.57 & 50.98 & $47 \mathrm{~min}$ \\
\hline Sulfated ash (w/w, \%) & - & 0.0015 & - & $0.020 \max$ \\
\hline Carbon residue (w/w, \%) & 0.697 & 0.033 & - & $0.050 \max$ \\
\hline Copper strip corrosion & - & $3 \mathrm{~h}, 50^{\circ} \mathrm{C} / 1 \mathrm{a}$ & - & No. 3 max \\
\hline \multicolumn{5}{|l|}{$\begin{array}{l}\text { Distillation temperature, } \\
90 \% \text { recovered }\left({ }^{\circ} \mathrm{C}\right)\end{array}$} \\
\hline IBP & & 338 & 161 & $360 \max$ \\
\hline $10 \%$ & & 340 & 202 & \\
\hline $20 \%$ & & 342 & 215 & \\
\hline $50 \%$ & & 348 & 254 & \\
\hline $90 \%$ & & 356 & 348 & \\
\hline Molecular weight $(\mathrm{g} / \mathrm{mol})$ & 872.50 & - & - & - \\
\hline
\end{tabular}

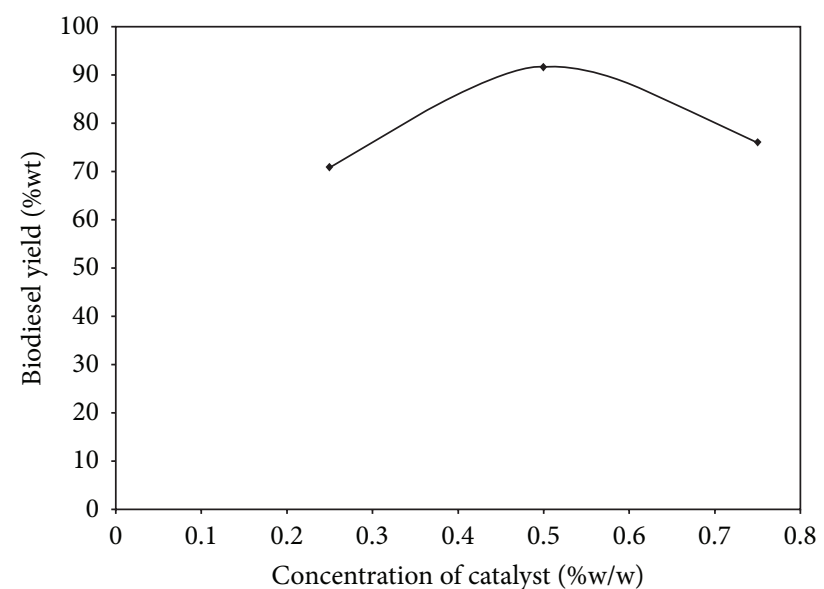

FIGURE 3: Effect of catalyst concentration on biodiesel yield (molar ratio of $6: 1$, reaction temperature of $60^{\circ} \mathrm{C}$, and reaction time of 60 minutes).

3.4. Effect of Catalyst Concentration on Biodiesel Production. The catalyst concentration is one of the most significant parameters which affects the biodiesel yield. Figure 3 shows the effect of $\mathrm{NaOH}$ catalyst concentration on the yield of biodiesel; during the process the other parameters are kept constant. It is observed that the biodiesel yield increases when catalyst concentration is increased from $0.25 \mathrm{w} / \mathrm{w} \%$ to $0.50 \mathrm{w} / \mathrm{w} \%$ and decreases when increased from $0.50 \mathrm{w} / \mathrm{w}$
$\%$ to $0.75 \mathrm{w} / \mathrm{w} \%$. The decrease in yield at $0.25 \mathrm{w} / \mathrm{w} \%$ of catalyst concentration may be due to incomplete reaction and at $0.75 \mathrm{w} / \mathrm{w} \%$ of catalyst concentration may be due to the fact that the higher amount of catalyst concentration favors the saponification reaction; thus further increase in catalyst concentration was not studied. From the present investigation, optimum amount of catalyst concentration was found to be $0.50 \mathrm{w} / \mathrm{w} \%$ with $90.69 \%$ biodiesel yield.

3.5. Effect of Reaction Time on Biodiesel Production. In order to study the effect of reaction time on production of biodiesel, the transesterification reaction was carried out by varying the reaction time as $45,60,75$, and 90 minutes and by keeping other process parameters constant. Figure 4 shows the effect of reaction time on the yield of biodiesel. Varying the reaction time from 45 to 60 minutes and 60 to 75 minutes, the percentage yield of biodiesel is increased. The percentage yield of biodiesel is decreased with further increase in reaction time from 75 to 90 minutes; this may be due to formation of more amount of soap. The highest percentage yield of biodiesel was noticed when the reaction time was 75 minutes and it is found to be $95.15 \%$.

3.6. Effect of Reaction Temperature on Biodiesel Production. Further experiments were conducted by keeping the reaction temperature at $40,50,60$, and $75^{\circ} \mathrm{C}$ in order to study the effect of reaction temperature. The catalyst concentration of $0.5 \mathrm{w} / \mathrm{w} \%$ and reaction time of 75 minutes were maintained. Figure 5 shows the effect of reaction temperature on biodiesel 


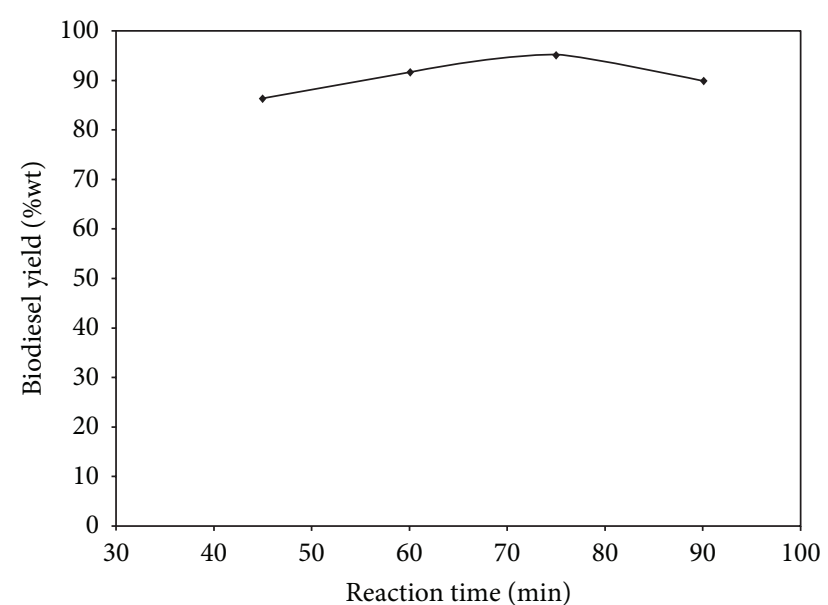

FIGURE 4: Effect of reaction time on biodiesel yield (molar ratio of $6: 1$, reaction temperature of $60^{\circ} \mathrm{C}$, and catalyst concentration of $0.5 \mathrm{w} / \mathrm{w} \%)$.

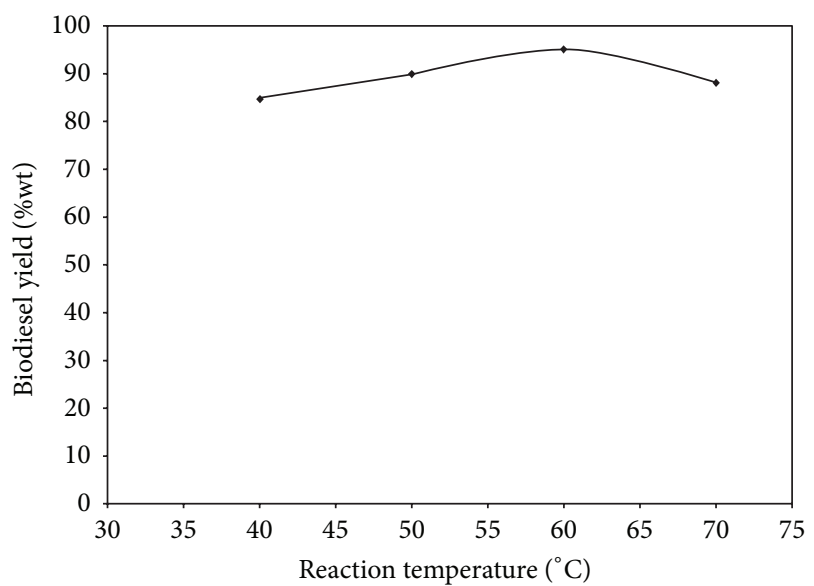

FIGURE 5: Effect of reaction temperature on biodiesel yield (molar ratio of $6: 1$, reaction time of 75 minutes, and catalyst concentration of $0.5 \mathrm{w} / \mathrm{w} \%)$.

yield. As the methanol boils at $65^{\circ} \mathrm{C}$, varying the reaction temperature from 40 to $60^{\circ} \mathrm{C}$ the biodiesel yield is increased and biodiesel yield was decreased at temperature of $70^{\circ} \mathrm{C}$; this may be attributed to occurrence of saponification reaction at higher temperature. The highest biodiesel yield is found to be $95.15 \%$ at $60^{\circ} \mathrm{C}$.

\section{Conclusions}

The purpose of the present study was to evaluate the sugar apple seed oil as a potential raw material for the production of biodiesel and to assess its feasibility for the replacement of petroleum fuel. The sugar apple seed oil was converted into biodiesel successfully by transesterification process and following conclusions were drawn.

(1) The sugar apple oil was converted to biodiesel by single stage base-catalyzed transesterification process without any pretreatment as the FFA content is found to be less than $1 \%$.

(2) The optimized process parameters are catalyst concentration of $0.5 \mathrm{w} / \mathrm{w} \%$, reaction time of 75 minutes and reaction temperature of $60^{\circ} \mathrm{C}$ with alcohol to oil molar ratio of $6: 1$, and constant stirrer speed. The biodiesel yield was found to be $95.15 \%$ at the optimized process parameters.

(3) The physical and chemical properties of biodiesel produced were found to be close to those of diesel fuel and also they meet the ASTM standard specifications for biodiesel.

\section{Conflict of Interests}

The authors declare that there is no conflict of interests regarding the publication of this paper.

\section{Acknowledgments}

Authors wish to thank Professor G. R. Naik, the Convener of Biodiesel Information and Demonstration Centre, Gulbarga University, Gulbarga, for permitting using the facilities available at the center for crushing of seeds for oil extraction and other test facilities and authors also thank supporting staff of centre, Mr. Pramod Kulkarni, Girish, and Ramesh for their support.

\section{References}

[1] "Energy statistics 2013," Central statistics office, National statistics organization, Ministry of statistics and programme implementation government of India, 2013, http://mospi.nic.in/ mospi_new/upload/Energy_Statistics_2013.pdf.

[2] C. P. Reddy, "Bio-diesel production through jatropha (ratan jyot) plantations in wastelands," Soil \& Water Conservation Today, vol. 2, no. 1, pp. 4-5, 2007.

[3] G. Knothe, "Biodiesel and renewable diesel: a comparison," Progress in Energy and Combustion Science, vol. 36, no. 3, pp. 364-373, 2010.

[4] H. J. Berchmans and S. Hirata, "Biodiesel production from crude Jatropha curcas L. seed oil with a high content of free fatty acids," Bioresource Technology, vol. 99, no. 6, pp. 1716-1721, 2008.

[5] P. Nakpong and S. Wootthikanokkhan, "Optimization of biodiesel production from Jatropha curcas L. oil via alkali-catalyzed methanolysis," Journal of Sustainable Energy \& Environment, vol. 1, no. 3, pp. 105-109, 2013.

[6] P. D. Patil, V. G. Gude, and S. Deng, "Biodiesel production from Jatropha curcas, waste cooking, and camelina sativa oils," Industrial \& Engineering Chemistry Research, vol. 48, no. 24, pp. 10850-10856, 2009.

[7] S. R. Kalbande and S. D. Vikhe, "Jatropha and Karanj bio-fuel: an alternate fuel for diesel engine," ARPN Journal of Engineering and Applied Sciences, vol. 3, no. 1, pp. 7-13, 2008.

[8] H. C. Ong, A. S. Silitonga, H. H. Masjuki, T. M. I. Mahlia, W. T. Chong, and M. H. Boosroh, "Production and comparative fuel properties of biodiesel from non-edible oils: Jatropha curcas, Sterculia foetida and Ceiba pentandra," Energy Conversion and Management, vol. 73, pp. 245-255, 2013. 
[9] L. C. Meher, V. S. S. Dharmagadda, and S. N. Naik, "Optimization of alkali-catalyzed transesterification of Pongamia pinnata oil for production of biodiesel," Bioresource Technology, vol. 97, no. 12, pp. 1392-1397, 2006.

[10] M. Naik, L. C. Meher, S. N. Naik, and L. M. Das, "Production of biodiesel from high free fatty acid Karanja (Pongamia pinnata) oil," Biomass and Bioenergy, vol. 32, no. 4, pp. 354-357, 2008.

[11] L. C. Meher, S. N. Naik, and L. M. Das, "Methanolysis of Pongamia pinnata (karanja) oil for production of biodiesel," Journal of Scientific and Industrial Research, vol. 63, no. 11, pp. 913-918, 2004.

[12] M. N. Nabi, S. M. N. Hoque, and M. S. Akhter, "Karanja (Pongamia Pinnata) biodiesel production in Bangladesh, characterization of karanja biodiesel and its effect on diesel emissions," Fuel Processing Technology, vol. 90, no. 9, pp. 1080-1086, 2009.

[13] P. K. Sahoo, L. M. Das, M. K. G. Babu, and S. N. Naik, "Biodiesel development from high acid value polanga seed oil and performance evaluation in a CI engine," Fuel, vol. 86, no. 3, pp. 448-454, 2007.

[14] A. S. Ramadhas, S. Jayaraj, and C. Muraleedharan, "Biodiesel production from high FFA rubber seed oil," Fuel, vol. 84, no. 4, pp. 335-340, 2005.

[15] O. E. Ikwuagwu, I. C. Ononogbu, and O. U. Njoku, "Production of biodiesel using rubber [Hevea brasiliensis (Kunth. Muell.)] seed oil," Industrial Crops and Products, vol. 12, no. 1, pp. 57-62, 2000.

[16] S. V. Ghadge and H. Raheman, "Process optimization for biodiesel production from mahua (Madhuca indica) oil using response surface methodology," Bioresource Technology, vol. 97, no. 3, pp. 379-384, 2006.

[17] V. B. Veljković, S. H. Lakićević, O. S. Stamenković, Z. B. Todorović, and M. L. Lazić, "Biodiesel production from tobacco (Nicotiana tabacum L.) seed oil with a high content of free fatty acids," Fuel, vol. 85, no. 17-18, pp. 2671-2675, 2006.

[18] M. Atapour and H.-R. Kariminia, "Characterization and transesterification of Iranian bitter almond oil for biodiesel production," Applied Energy, vol. 88, no. 7, pp. 2377-2381, 2011.

[19] S. M. P. Meneghetti, M. R. Meneghetti, C. R. Wolf et al., "Ethanolysis of castor and cottonseed oil: a systematic study using classical catalysts," Journal of the American Oil Chemists' Society, vol. 83, no. 9, pp. 819-822, 2006.

[20] M. H. Chakrabarti and R. Ahmad, "Transesterification studies on castor oil as a first step towards its use in biodiesel production," Pakistan Journal of Botany, vol. 40, no. 3, pp. 1153-1157, 2008.

[21] F. Anwar, U. Rashid, M. Ashraf, and M. Nadeem, "Okra (Hibiscus esculentus) seed oil for biodiesel production," Applied Energy, vol. 87, no. 3, pp. 779-785, 2010.

[22] Y. C. Sharma and B. Singh, "An ideal feedstock, kusum (Schleichera triguga) for preparation of biodiesel: optimization of parameters," Fuel, vol. 89, no. 7, pp. 1470-1474, 2010.

[23] H. Manjunath, H. Omprakash, and R. K. Hemachandra, "Process optimization for biodiesel production from Simarouba, Mahua, and waste cooking oils," International Journal of Green Energy, vol. 12, no. 4, pp. 424-430, 2014.

[24] U. Rashid, F. Anwar, R. Yunus, and A. H. Al-Muhtaseb, "Transesterification for biodiesel production using Thespesia populnea seed oil: an optimization study," International Journal of Green Energy, vol. 12, no. 5, pp. 479-484, 2014.

[25] B. Panchal, S. Dhoot, S. Deshmukh, and M. Sharma, "Optimization of extraction of oil and biodiesel from Thespesia populnea seed oil by alkali-catalyst in India," International Journal of Green Energy, 2012.

[26] M. Ahmad, M. Zafar, S. Sultana, A. Azam, and M. A. Khan, "The optimization of biodiesel production from a novel source of wild non-edible oil yielding plant Silybum marianum," International Journal of Green Energy, vol. 11, no. 6, pp. 589-594, 2014.

[27] H. Sadia, M. Ahmad, M. Zafar, S. Sultana, A. Azam, and M. A. Khan, "Variables effecting the optimization of non edible wild safflower oil biodiesel using alkali catalyzed transesterification," International Journal of Green Energy, vol. 10, no. 1, pp. 53-62, 2013.

[28] http://eol.org/pages/1054831/overview.

[29] K. V. Yathish, B. R. Omkaresh, and R. Suresh, "Biodiesel production from custard apple seed (Annona Squamosa) oil and its characteristics study," International Journal of Engineering, vol. 2, no. 5, pp. 31-36, 2013.

[30] https://www.hort.purdue.edu/newcrop/morton/sugar_apple.html.

[31] M. M. Azam, A. Waris, and N. M. Nahar, "Prospects and potential of fatty acid methyl esters of some non-traditional seed oils for use as biodiesel in India," Biomass \& Bioenergy, vol. 29, no. 4, pp. 293-302, 2005. 


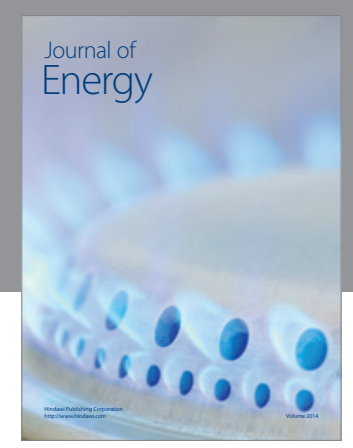

Journal of

Industrial Engineering
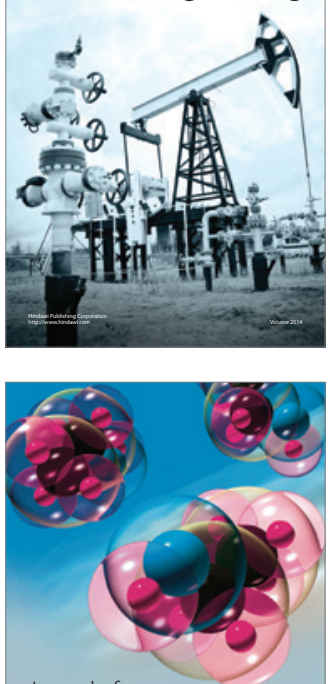

Fuels
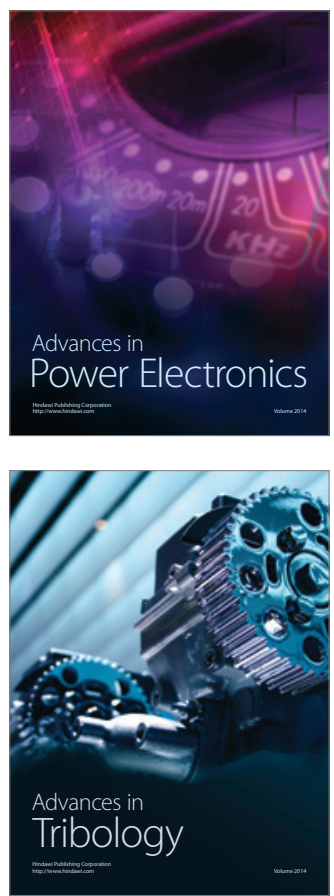

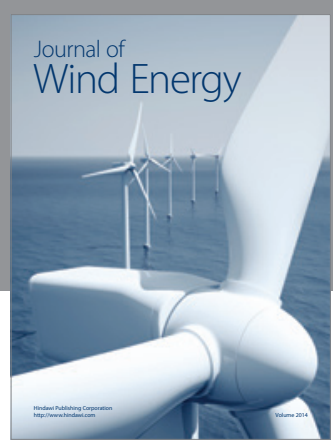

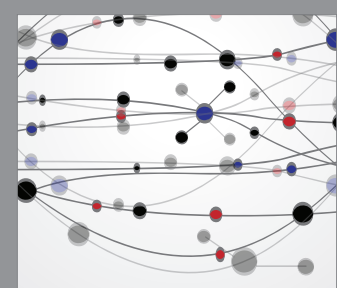

The Scientific World Journal

Submit your manuscripts at http://www.hindawi.com

Journal of

Structures
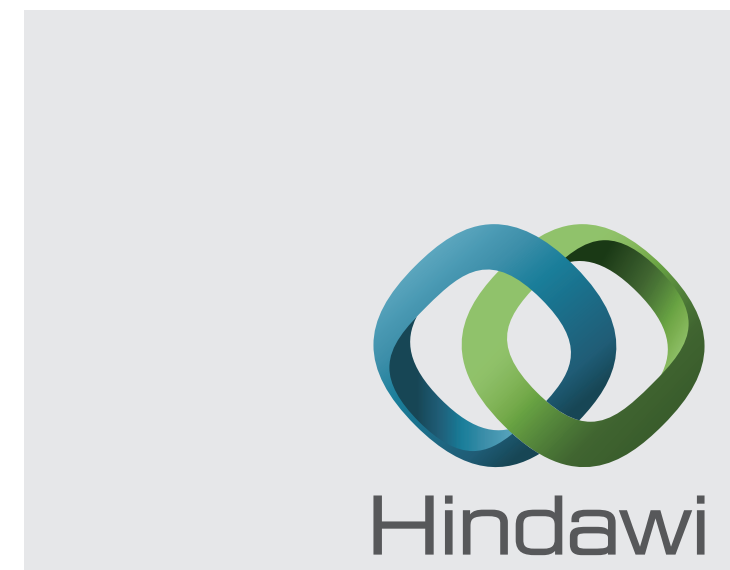

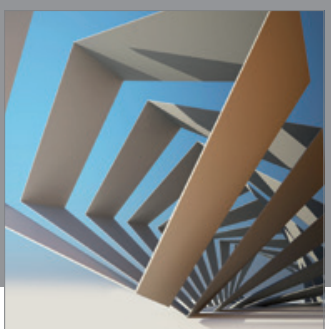

Rotating

Machinery
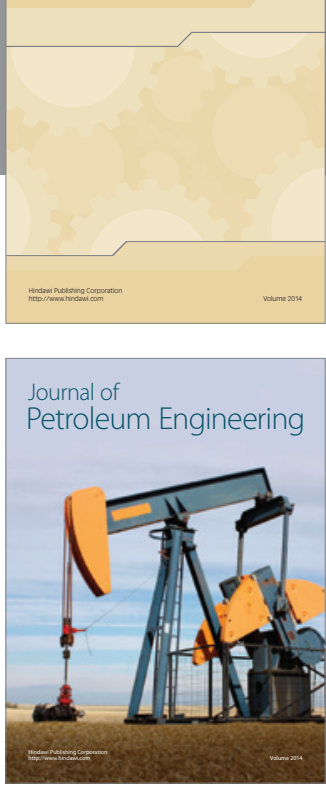

Journal of

Solar Energy
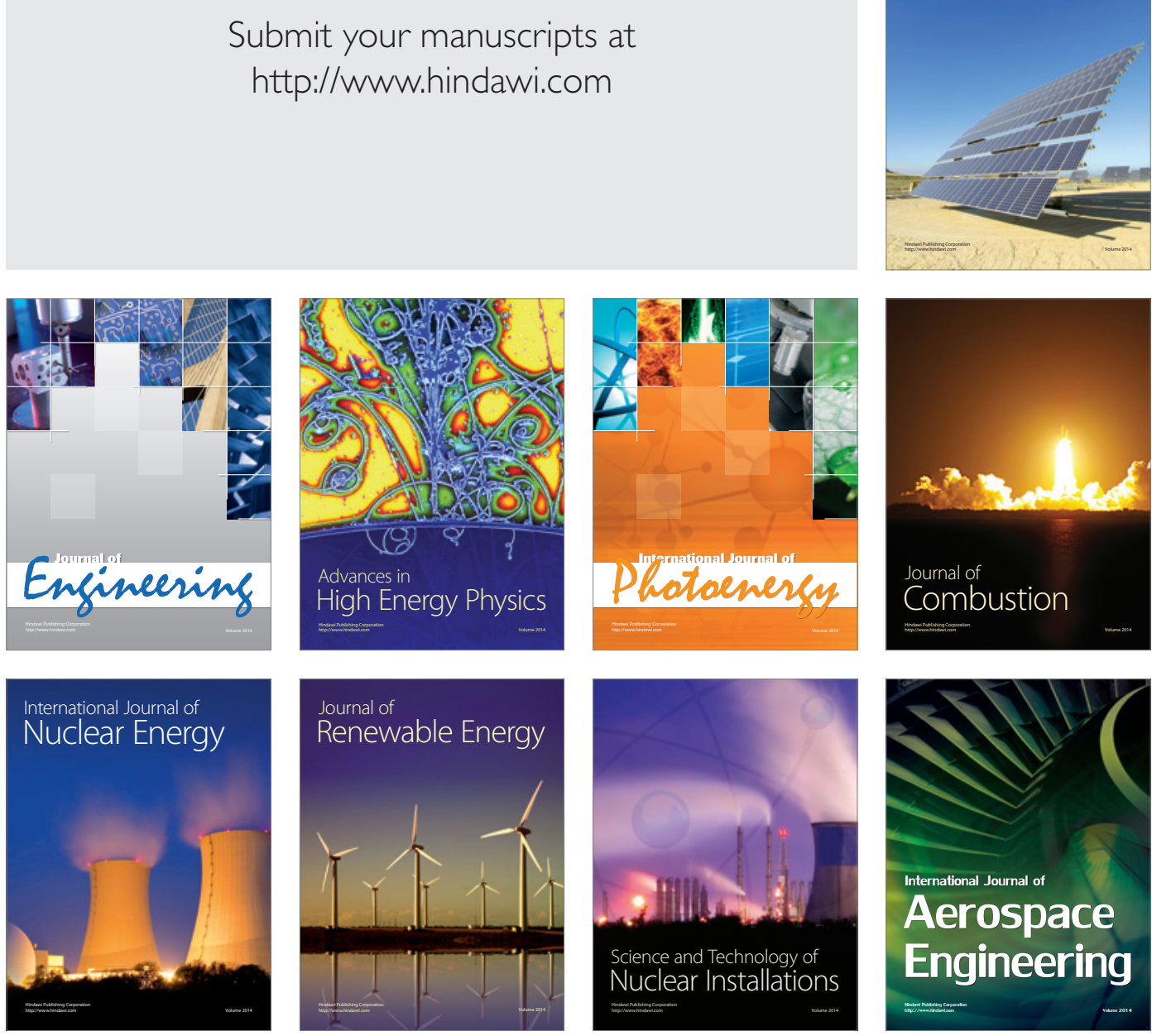